\title{
KEPEMIMPINAN KEPALA SEKOLAH DALAM MENINGKATKAN PROFESIONALISME GURU DI SMP NEGERI 40 PURWOREJO
}

\author{
Siti Zulaikah \\ (SMP Negeri 18 Purworejo) \\ sitizulaikah403@gmail.com
}

\begin{abstract}
ABSTRAK
Penelitian ini didasari oleh kepemimpinan kepala sekolah yang cukup baik. Sehubungan dengan hal itu, penelitian ini bertujuan untuk mengetahui kepemimpinan kepala sekolah dalam meningkatkan profesionalisme guru di SMP Negeri 40 Purworejo. Penelitian ini menggunakan penelitian kualitatif yang menitik beratkan pada gejala secara alamiah dan dianalisis dengan menggunakan logika berpikir ilmiah. Adapun teknik pengumpulan data pada penelitian ini diperoleh melalui observasi, wawancara, dokumentasi, dan triangulasi. Analisis data dilakukan dengan reduksi data, penyajian data, dan verifikasi data kemudian merumuskan kesimpulan hasil penelitian yang dilakukan. Ada tiga hal yang dikemukakan dalam penelitian ini, yaitu: (1) kemampuan manajerial kepala sekolah kaitannya dengan chief officer dalam meningkatkan profesionalisme guru di SMP Negeri 40 Purworejo terbukti nyata menghasilkan produk visi dan misi sekolah yang telah dilaksanakan dengan baik meskipun masih belum semuanya, dan untuk mencapainya dibutuhkan kerja sama yang baik dengan semua elemen sekolah; peran dari kepala sekolah untuk menciptakan suasana yang harmonis di lingkungan sekolah, dengan memberikan tugas guru sesuai tupoksinya dan guru dapat menjalankan tugas dan tanggungjawabnya dengan profesional; memberi kesempatan kepada tenaga pendidik untuk meningkatkan profesinya; (2) kemampuan Sense of business Kepala Sekolah dalam meningkatkan profesionalisme guru, dibuktikan dengan kemampuan kepala sekolah dalam mengelola dana pendidikan terutama dalam mencari sumber dana pendidikan untuk mencukupi kebutuhan dalam penyelenggaraan pendidikan; (3) kemampuan sense of education kepala sekolah dalam meningkatkan profesionalisme guru, yang di buktikan dengan kemampuan kepala sekolah dalam melakukan pembinaan mental, pembinaan moral, pembinaan fisik dan pembinaan artistik yang di laksanakan secara terprogram.
\end{abstract}

Kata Kunci: Kepemimpinan Kepala Sekolah, Profesionalisme Guru

\section{PENDAHULUAN}

Pendidikan merupakan sesuatu yang sangat esensial bagi pembentukan karakter sebuah peradaban dan kemajuan suatu bangsa. Tanpa adanya pendidikan, sebuah bangsa atau masyarakat tidak akan pernah mendapatkan kemajuannya sehingga menjadi bangsa atau masyarakat yang kurang atau bahkan tidak beradab. Oleh karena itu pembangunan 
pendidikan merupakan bagian penting dalam upaya menyeluruh dan bersungguhsungguh untuk meningkatkan harkat dan martabat bangsa.

Melalui pendidikan di harapkan akan terbentuk manusia-manusia yang cerdas dalam berbagai aspeknya, baik intelektual, sosial, emosional maupun spiritual, terampil serta berkepribadian, dan dapat berperilaku dengan dihiasi akhlak mulia yang nantinya akan mampu mengisi kehidupannya secara produktif bagi kepentingan dirinya dan masyarakat. Hal ini sesuai dengan tujuan Pendidikan Nasional yang termuat dalam UU No 20 Tahun 2003 yakni Pendidikan Nasional berfungsi mengembangkan kemampuan dan membentuk watak serta peradaban bangsa yang bemartabat dalam rangka mencerdaskan kehidupan bangsa, bertujuan untuk berkembangnya potensi peserta didik agar menjadi manusia yang beriman dan bertakwa kepada Tuhan Yang Maha Esa, berakhlak mulia, sehat, berilmu, cakap, kreatif, mandiri, dan menjadi warga negara yang demokratis serta bertanggung jawab. ${ }^{1}$

Usaha untuk mencapai tujuan pendidikan di atas bukanlah sesuatu yang mudah, namun di perlukan suatu usaha yang optimal dan bersungguh-sungguh dalam penyelenggaraan pendidikan agar dapat menghasilkan lulusan yang berkualitas. Kualitas dan kuantitas pendidikan yang di lakukan saat ini akan menentukan ketersediaan sumber daya manusia di masa yang akan datang.

Eliyanto menjelaskan bahwa personil sekolah memegang peranan penting dalam menentukan kelancaran pelaksanaan program sekolah. Personil sekolah menentukan pencapaian visi sekolah. Betapapun lengkap dan modernnya sarana dan prasarana serta metode kerja yang ada dalam sekolah, tetapi bila kemampuan manusia yang menjalankan programnya tidak memadai, maka tujuan pendidikan akan sulit tercapai. ${ }^{2}$

Guru merupakan salah satu komponen pendidikan yang menjadi salah satu faktor penentu keberhasilan tujuan pendidikan, karena guru adalah orang yang berhubungan dengan siswa secara langsung, sehingga gurulah yang memiliki kesempatan lebih banyak untuk mendidik siswa agar dapat menjadi generasi muda yang berpendidikan, bermoral baik, serta mencintai budaya Indonesia. Jika diibaratkan dalam dunia perfilman, guru ini adalah tokoh utamanya.

\footnotetext{
${ }^{1}$ UU RI No 20 Tahun 2003 tentang SISDIKNAS.

2 Eliyanto. Manajemen Sumber Daya Manusia (MSDM) Pendidikan. (Yogyakarta: UIN Sunan Kalijaga, 2018), hlm.34.
} 
Guru adalah tulang punggung dalam kegiatan pendidikan, terutama yang berkaitan dengan kegiatan proses belajar mengajar. Tanpa adanya peran guru maka proses belajar mengajar akan terganggu bahkan dapat dikatakan gagal. Dan untuk dapat menghasilkan output berupa siswa yang berkualitas, seorang guru harus berkompeten di bidangnya.

Sekarang ini perkembangan profesional guru merupakan perkembangan yang seharusnya berlangsung secara berkesinambungan, mengingat perubahan dan pemahaman tentang masalah-masalah pendidikan yang selalu berkembang. Seorang guru diharapkan mampu dan peduli terhadap berbagai permasalahan di lingkungan terutama yang menyangkut tanggungjawabnya terhadap profesionalitas dalam proses belajar mengajar.

Dalam Undang-Undang Nomor 14 Tahun 2005 tentang Guru dan Dosen menegaskan bahwa yang dimaksud guru adalah pendidik profesional dengan tugas utama mendidik, mengajar, membimbing, mengarahkan, melatih, menilai, dan mengevaluasi peserta didik di jalur pendidikan formal, pendidikan dasar, dan pendidikan menengah. ${ }^{3}$ Di samping itu, di era global saat ini, dituntut adanya fungsi dari keberadaan guru sebagai tenaga profesional, yang mampu meningkatkan martabat serta mampu melaksanakan sistem pendidikan nasional dan mewujudkan tujuan pendidikan nasional, yaitu berkembangnya potensi peserta didik agar menjadi manusia yang beriman dan bertakwa kepada Tuhan Yang Maha Esa, berakhlak mulia, sehat, berilmu, cakap, dan kreatif.

Seorang pendidik selain dituntut untuk membuat peserta didik menjadi lebih paham dengan apa yang disampaikan, juga harus dapat membuat peserta didik mendapatkan tambahan ilmu dan memiliki wawasan yang luas, memberikan pengaruh yang baik pada pembentukan sumber daya manusia (human capital) dalam aspek kognitif, afektif maupun psikomotor, baik secara mental maupun spiritual. Hal ini jelas menuntut kualitas penyelenggaraan pendidikan yang baik serta pendidik yang profesional, agar kualitas hasil pendidikan dapat benar-benar berperan optimal dalam kehidupan masyarakat. Untuk itu pendidik dituntut untuk selalu memperbaiki, mengembangkan diri dalam membangun dunia pendidikan.

\footnotetext{
${ }^{3}$ UU RI No. 14 Tahun 2005 tentang Guru dan Dosen.
} 
Namun dalam kenyataanya masih di temui adanya guru di dalam melaksanakan proses belajar mengajarnya yang belum maksimal, kurangnya penguasaan materi, dan kurangnya memahami metode pembelajaran. Ada guru yang bersemangat dan penuh tanggung jawab, namun ada juga guru dalam melakukan pekerjaan tanpa dilandasi dengan rasa tanggungjawab, dalam arti tidak sesuai dengan kinerja guru yang diharapkan. Selain itu juga ada guru yang datang terlambat ketika jam pembelajaran.

Dalam proses belajar mengajar, sebelum melaksanakan dan sesudahnya terdapat administrasi yang harus disiapkan oleh guru. Administrasi guru ini dapat berupa RPP, silabus, jurnal, kalender pendidikan, program tahunan, program semester, analisis $\mathrm{SK} / \mathrm{KD}$, prosedur penilaian, KKM, buku presensi, dan lain sebagainya. Masih ada sebagian besar guru yang beranggapan bahwa pekerjaan administrasi tersebut menyusahkan guru, padahal sesungguhnya administrasi tersebut memudahkan guru dalam melaksanakan kegiatan belajar mengajar, sehingga tidak semua guru tertib dalam membuat administrasi guru tersebut. Administrasi guru yang harusnya dibuat oleh guru yang bersangkutan, seringkali hanyalah hasil dari copy paste dari waktu ke waktu tanpa ada perubahan dan perbaikan. Hal ini pula yang terjadi di SMP Negeri 40 Purworejo sehingga kepemimpinan kepala sekolah harus mampu memberikan kontribusi dalam meningkatkan profesionalisme guru.

Mengingat besar tanggung jawab dan peran seorang guru sebagai tenaga pelaksana pembelajaran disekolah, maka seorang guru harus memiliki kemampuan profesional. Kekurangan dan kelemahan yang terdapat pada guru dalam menjalankan tugasnya sebagai pendidik dan pengajar maka di perlukan kepemimpinan kepala sekolah yang baik untuk membimbing dan mengarahkan para guru sebagaimana mestinya, dan pembinaan profesionalisme guru secara terus menerus mutlak diperlukan.

Kualitas kepemimpinan kepala sekolah dapat diketahui dari sejauhmana keberhasilan sekolah yang dipimpinnya. ${ }^{4}$ Lebih jauh di jelaskan bahwa seorang pemimpin ditentukan oleh sejauhmana keberhasilannya melakukan perubahan dan membawa organisasi serta pengikutnya ke arah yang lebih baik. Keberhasilan sekolah dapat diketahui melalui kepuasan warga sekolah maupun masyarakat, kualitas kompetensi lulusannya, dan pelayanannya. Seorang pemimpin sudah selayaknya dapat

\footnotetext{
${ }^{4}$ Eliyanto. Op.Cit., hlm.25.
} 
menjadi panutan bagi pengikutnya. Sebagaimana menurut Khan, et al., "Leaders have to provide whit guidelines and motivate others towards accomplishment of tasks. "5

Masalah kepemimpinan kepala sekolah memberikan kesan yang menarik, hal ini di sebabkan karena suatu organisasi akan berhasil atau gagal sebagian ditentukan oleh kualitas kepemimpinan. Kepemimpinan merupakan kemampuan untuk mempengaruhi, menggerakkan dan mengarahkan tindakan pada seseorang atau kelompok orang untuk mencapai tujuan tertentu pada situasi tertentu. Kepemimpinan merupakan salah satu aspek manajerial dalam kehidupan berorganisasi yang merupakan posisi kunci. Karena kepemimpinan seorang pemimpin berperan sebagai penyelaras dalam proses kerjasama antar manusia dalam organisasinya.

Menurut Soebagio menjelaskan bahwa kepemimpinan pendidikan memerlukan perhatian yang utama, karena melalui kepemimpinan yang baik diharapkan akan lahir tenaga-tenaga berkualitas dalam berbagai bidang sebagai pemikir, pekerja yang pada akhirnya dapat meningkatkan sumber daya manusia yang berkualitas. ${ }^{6}$

Studi keberhasilan kepala sekolah menurut Wahjosumidjo menunjukkan bahwa kepala sekolah adalah seorang yang menentukan titik pusat dan irama suatu sekolah. Bahkan lebih jauh studi tersebut menyimpulkan bahwa keberhasilan sekolah adalah keberhasilan kepala sekolah. ${ }^{7}$ Hal senada seperti yang di sampaikan oleh Huber menyatakan "leadership is a central factor for the quality of a shcool". ${ }^{8}$ Kepemimpinan adalah suatu pokok untuk kualitas sekolah. Kepala sekolah dilukiskan sebagai seorang yang memiliki harapan yang tinggi bagi para staf dan para peserta didik. Kepala sekolah adalah mereka yang banyak mengetahui tugas-tugas mereka dan mereka yang menentukan irama bagi sekolah mereka.

Ketercapaian tujuan pendidikan sangat tergantung pada kecakapan dan kebijaksanaan seorang kepala sekolah sebagai pucuk pimpinan di lembaga pendidikan tersebut. Kepala Sekolah sebagai pejabat professional yang ada dalam organisasi

\footnotetext{
${ }^{5}$ Khan, M.M.,et al. Transformasional, transactional, and laissez-fier.e style of teaching faculty as pradictors of satisfaction, and extra effort among the studens: Evidence from higher education institution. Interdisciplinery. (Journal of Human And Social Sciences, Vo.3, No.6, Th.2011), hlm.250.

${ }^{6}$ Soetjipto, dkk, Profesi Keguruan, (Jakarta: Rineka Cipta, 2009 ), hlm.42-43.

${ }^{7}$ Wahyosumidjo. Kepemimpinan Kepala Sekolah Tinjauan Teoritik Dan Permasalahannya. (Jakarta: Raja Grafindo Persada, 2010), hlm.83.

${ }^{8}$ Huber, S.G.(2004). Scool leadership and leadership development. Adjusting leadership teories and development program to values and the core of scool. (Jurnal of Educatiaon Administrasion, Vol.42, No.6, Th.2004), hlm.669.
} 
sekolah, bertugas untuk mengatur semua sumber daya sekolah dan bekerjasama dengan guru-guru, staf, dan pegawai lainnya dalam mendidik peserta didik untuk mencapai tujuan pendidikan. Kepala sekolah adalah pemimpin yang mempunyai peranan penting dalam mengembangkan lembaga pendidikannya.

Berkaitan hal tersebut, kepemimpinan kepala sekolah dalam meningkatkan profesionalisme guru sangat diperlukan, dan untuk mewujudkannya diperlukan kemampuan-kemampuan yang mendasar seorang kepala sekolah dalam mengemban tugas dan tanggung jawabnya sebagai pimpinan di sekolah agar dapat berjalan dengan baik, tepat dan efektif.

Tugas kepala sekolah sebagai pemimpin pendidikan bukanlah pekerjaan yang mudah. Sebagai pemimpin lembaga pendidikan, kepala sekolah harus mampu mendorong kinerja para bawahan agar bekerja secara sukarela, menampilkan kinerja yang tinggi untuk mencapai standar mutu yang diharapkan oleh orang tua, masyarakat, industri dan pemerintah. ${ }^{9}$

Dalam peranannya sebagai seorang pendidik, kepala sekolah harus mampu menanamkan, memajukan, dan meningkatkan nilai mental, moral, fisik dan artistik kepada para guru atau tenaga fungsional yang lainnya, tenaga administrasi (staf) dan kelompok para siswa atau peserta didik. Untuk menanamkan peranannya ini kepala sekolah harus menunjukkan sikap persuasif dan keteladanan. Sikap persuasif dan keteladanan inilah yang akan mewarnai kepemimpinan termasuk di dalamnya pembinaan yang dilakukan oleh kepala sekolah terhadap guru yang ada di sekolah tersebut.

Kepala sekolah sebagai edukator, supervisor, motivator yang harus melaksanakan pembinaan kepada para karyawan, dan para guru di sekolah yang dipimpinnya karena faktor manusia merupakan faktor sentral yang menentukan seluruh gerak aktivitas suatu organisasi, walau secanggih apapun teknologi yang digunakan tetap faktor manusia yang menentukannya. ${ }^{10}$

\footnotetext{
${ }^{9}$ Syafaruddin. Manajemen Mutu Terpadu dalam Pendidikan. (Jakarta: Grasindo Widia Sarana Indonesia, 2002), hlm.35.

10 Arikunto, Suharsimi. Manajemen Pengajaran Secara Manusiawi, (Jakarta: Rineka Cipta, 2010), hlm.238-240.
} 
Busher dan Barker menyatakan, "leaders are mediators of the social and curriculum contexts of scool for staff, studens, and parents to make teaching and leaning relevant relevant and appropriately differenciated". ${ }^{11}$ Pemimpin (kepala sekolah) merupakan mediator dalam hubungan social dan kurikulum bagi seluruh staf, siswa, dan orang tua untuk menciptakan pengajaran dan pembelajaran yang relevan dan sesuai dengan perubahan. Kepala sekolah sebagai bagian kepemimpinan pendidikan berperan dalam memimpin dan mengelola tim kerja untuk mencapai tujuan organisasi/sekolah.

SMP Negeri 40 Purworejo sebagai sekolah menengah negeri yang masih tergolong muda yang terletak di daerah pinggiran kabupaten Purworejo, membutuhkan pemimpin/ kepala sekolah yang mampu bersaing dengan sekolah-sekolah negeri yang lain. Untuk itu kepala sekolah sebagai pemimpin sekolah mempunyai tugas yang sangat berat dalam rangka meningkatkan kualitas sekolah dan guru sebagai salah satu komponen yang terpenting dalam pendidikan, terutama dalam hal mengatasi berbagai permasalahan yang berkaitan dengan peningkatan mutu pendidikan, dituntut untuk bisa menjadi guru profesional.

Kemampuan kepemimpinan kepala sekolah yang lemah dan tidak maksimal dalam upaya meningkatkan profesionalisme guru terutama di SMP Negeri 40 Purworejo menjadikan mutu pendidikan menjadi berkurang dan tertinggal di bandingkan dengan sekolah- sekolah negeri yang lain baik di bidang akademis maupun non akademis.

Bertolak dari kemampuan kepemimpinan kepala sekolah yang telah di diuraikan di atas, di mana seorang kepala sekolah harus mampu mengelola sumber daya yang ada di sekolah, menjadi pemimpin menjadi pendidik bagi seluruh warga sekolah, seorang kepala sekolah harus mampu melaksanakan tanggungjawab sesuai dengan situasi dan kondisi yang ada di sekolah tersebut. Selanjutnya, yang tidak kalah penting adalah seorang gurupun harus mampu mengembangkan diri untuk meningkatkan pengetahuan dan kemampuan yang diperlukan guna peningkatan profesionalitas dalam proses belajar mengajar. Kiranya tidak berlebihan ketika peneliti ingin mencoba memaparkan penelitian ini dengan judul "Kepemimpinan Kepala Sekolah Dalam Meningkatkan Profesionalisme Guru di SMP Negeri 40 Purworejo.”

\footnotetext{
11 Busher,H. Understanding educational leadership: Peopele, power, and culture. (New York: Open Uunivercity Press, 2003), hlm.12.
} 


\section{KAJIAN LITERATUR}

\section{Kepemimpinan Kepala Sekolah}

Keberhasialan suatu lembaga pendidikan tergantung pada kepemimpinan kepala sekolah. Karena ia merupakan pemimpin di lembaganya, maka ia harus harus mampu membawa lembaganya kearah tercapainya tujuan yang telah di tetapkan. Peran utama kepala sekolah sebagai pemimpin pendidikan adalah menciptaka situasi mengajar sehinga guru-guru dapat mengajar, dan murid-murid dapat belajar.

Kepala sekolah harus mampu menciptakan situasi belajar mengajar dengan baik. Ini berarti bahwa kepala sekolah harus mampu mengelola "school plant", pelayanan-pelayanan khusus sekolah, dan memfasilitasi guru-guru dan murid-murid agar memperoleh kepuasan menikmati kondisi-kondisi kerja; mengelola personalia pengajar dan murid; membina kurikulum yang memenuhi kebutuhan anak; dan mengelola catatan-catatan pendidikan. Kesemuanya ini di harapkan, agar ia dapat memajukan program pengajaran di sekolahnya. ${ }^{12}$

Geovani dan Elliot menjelaskan bahwa keberadaan kepala sekolah mempunyai fungsi utama bagi sekolah yang di kelolanya, yakni: Pertama, kepala sekolah sebagai admionistrator. Dalam fungsi ini kepala sekolah berfungsi melaksanakan fungsi-fungsi administrasi pendidikan di sekolah. Dan tugas-tugas tersebut meliputi pengelolaan yang bersifat administratif dan operatif. Kedua, Kepala sekolah sebagai educator. Dalam fungsi ini kepala sekolah bertugas melaksanakan tugas-tugas sebagai edukatif dalam pendidikan. ${ }^{13}$

Sedangkan Mulyasa menjelaskan kepemimpinan kepala sekolah yang efektif memiliki kriteria sebagai berikut:

1. Kepala sekolah harus mampu memberdayakan guru-guru untuk melaksanakan poses pembelajaran dengan baik, lancar, dan produktif.

2. Kepala sekolah harus dapat menyelesaikan tugas dan pekerjaan yang menjadi tugas dan tanggungjawabnya dengan waktu yang telah ditetapkan.

3. Kepala sekolah harus mampu menjalin hubungan yang harmonis dengan masyarakat baik masyarakat disekitar lingkungan kerja ataupun masyarakat dilain tempat sehingga dapat melibatkan secara aktif dalam rangka mewujudkan tujuan sekolah dan pendidikan.

4. Kepala sekolah harus mampu menerapkan prinsip kepemimpinan yang sesuai dengan tingkat kedewasaan guru dan karyawan sekolah.

\footnotetext{
12 Soetjipto, dkk, Profesi Keguruan, (Jakarta: Rineka Cipta, 2009 ), h1m.19.

${ }^{13}$ Arifin, Anwar. Strategi Komunikasi, Sebuah Pengantar Ringkas. (Bandung: Armico, 1994), hlm.48.
} 
5. Kepala sekolah harus mampu bekerja dengan tim manajemen.

6. Kepala sekolah harus berusaha agar berhasil mewujudkan tujuan sekolah secara produktif sesuai dengan ketentuan yang telah ditetapkan. ${ }^{14}$

Kepala sekolah merupakan tokoh kunci keberhasilan sekolah, kepala sekolah adalah kunci kesuksesan pendidikan di madrasah atau di sekolah. Sudarwan Danim menyebutkan kepala sekolah sebagai the key person- penanggung jawab utama atau factor kunci untuk membawa sekolah menjadi center of excellence, pusat keunggulan dalam mencetak dan mengembangkan sumber daya manusia (SDM) sekolah. Apakah sekolah itu menjadi efektif, menjadi sekolah yang sukses, atau sebaliknya, semua tergantung dengan peran seorang kepala sekolah. ${ }^{15}$

Reinhartz \& Beach mengemukakan bahwa "leadership involves building cohesive and goal oriented teams the are capable of working together to accomplish objective and fulfill the mission." 16 Kepemimpinan melibatkan membangun tim yang kompak dan berorientasi pada tujuan yang mampu bekerjasama untuk mencapai tujuan.

Kepemimpinan adalah proses pemimpin dalam mengarahkan bawahan untuk mencapai tujuan yang telah ditetapkan dengan cara memotivasi, mengambil keputusan, mengawasi, mengarahkan, mempengaruhi, dan cara lain yang dapat dilakukan agar bawahan tetap melaksanakan tugas dan tanggungjawabnya. Sedangkan Kepala Sekolah adalah guru yang diberikan tanggungjawab yang lebih dan cara lain yang dapat dilakukan agar bawahan tetap melaksanakan tugas dan tanggungjawabnya.

Kepala sekolah sebagai pemimpin tertinggi yang sangat berpengaruh dan menentukan kemajuan sekolah harus memiliki kemampuan administrasi, memiliki komitmen tinggi dalam melaksanakan tugasnya. Kepemimpinan kepala sekolah yang baik harus dapat mengupayakan peningkatan kinerja guru. Karena kinerja guru merupakan penentu tinggi rendahnya kualitas pendidikan. Pendidikan dinyatakan berkualitas apabila seluruh komponen yang ada dalam lembaga pendidikan tersebut bekerja mengacu pada visi, misi, tujuan dan sasaran yang ada, dan kepala sekolah

\footnotetext{
${ }_{14}$ Mulyasa, E. Uji Kompetensi dan Penilaian Kinerja Guru. (Bandung: Remaja Rosda Karya, 2017), hlm.126.

${ }^{15}$ Danim, Sudarwan. Visi Baru Manajemen, (Jakarta: Bumi Aksara, 2005), hlm.96.

${ }^{16}$ Reinhartz \& Beach. Educational leadership: Changing scool, changing rooles. (Boston: pearson Education, 2004), hlm.3.
} 
mampu untuk menggerakkan seluruh potensi sumber daya yang ada di lembaga pendidikan.

Pucuk pimpinan di sekolah bukan seperti di perusahaan yang menekankan kepada untung rugi suatu usaha. Walaupun demikian, sekolah tetap memperhitungkan segi benefit (kebermanfaatan suatu usaha), hal ini berimplikasi pada profit yang lebih sebagai pemimpin yang memiliki amanah menciptakan budaya positif yang relevan dengan produktifitas sekolah, bukan sebagai penguasa yang memaksakan kehendaknya dan otoritasnya.

Lebih lanjut di jelaskan bahwa kemampuan tersebut diatas mengharuskan seorang pemimpin (kepala sekolah) menguasai sejumlah ilmu pengetahuan manajemen, khususnya manajemen pendidikan, dan penguasaan strategi yang harus memperhatikan bahwa suatu strategi yang mantap hanya dapat di laksanakan di dalam suatu organisasi yang efisien. Maka seorang pemimpin yang professional harus menguasai dan mengembangkan struktur organisasi pendidikan sehingga sumber daya yang tersedia, baik sumber daya manusia maupun sumber dana serta infrastruktur lainnya dapat di manfaatkan seoptimal mungkin.

Dari sinilah dapat di jelaskan bahwa kepala sekolah yang profesional di tuntut mempunyai kemampuan dalam konteks sebagai:

1. Pemimpin (kepala pegawai), yaitu kepala sekolah sebagai manajer harus memiliki strategi yang tepat untuk memberdayakan tenaga kependidikan melalui kerjasama yang kooparatif, memberikan kesempatan kepada tenaga kependidikan untuk meningkatkan profesinya dan mendorong keterlibatan seluruh tenaga kependidikan dalam berbagai kegiatan yang menunjang program sekolah.

2. Pengelola organisasi, yang menekankan pada keterampilan mengelola organisasi yang mengarah pada kelancaran sistem kerja dalam organisasi tersebut.

3. Pendidik, yang menekankan pada strategi pendidikan itu dilaksanakan. Untuk kepentingan tersebut kepala sekolah harus berusaha menanamkan, memajukan dan meningkatkan sedikitnya empat macam nilai, yakni pembinaan mental, moral, fisik dan artistik.

Kepemimpinan kepala sekolah berkaitan dengan berbagai tugas dan fungsi yang harus diembannya dalam mewujudkan sekolah efektif, produktif, mandiri, dan akuntabel. Dari berbagai tugas dan fungsi yang harus diembannya tersebut sedikitnya 
terdapat sepuluh kunci kepemimpinannya yaitu mencakup visi yang utuh, tanggung jawab, keteladanan, memberikan layanan terbaik, mengembangkan orang, membina rasa persatuan dan kesatuan, fokus pada peserta didik, manajemen yang mengutamakan praktik, menyesuaikan gaya kepemimpinan, dan memanfaatkan kekuasaan keahlian.

Dari uraian di atas dapat di ambil kesimpulan bahwa kepemimpinan kepala sekolah adalah proses memimpin dan mengarahkan bawahan yang dilakukan oleh kepala sekolah untuk mencapai tujuan pendidikan yang telah ditetapkan dengan cara mengambil keputusan, mengawasi, mengarahkan, mempengaruhi, dan cara lain yang dapat dilakukan agar bawahan tetap melaksanakan tugas dan tanggungjawabnya.

\section{Profesionalisme Guru}

Dalam menghadapi tuntunan situasi perkembangan zaman dan pembangunan nasional, sistem pendidikan nasional harus dapat dilaksanakan secara tepat guna dan hasil guna dalam berbagai aspek dimensi,jenjang dan tingkat pendidikan. Keadaan semacam itu pada gilirannya akan menuntut para pelaksana dalam bidang pendidikan diberbagai jenjang untuk mampu menjawab tuntutan tersebut melalui fungsi-fungsinya sebagai guru.

Penting dan strategisnya guru dalam upaya mengembangkan potensi siswa tampaknya tidak akan pernah tergantikan oleh yang lain, bahkan guru memegang peranan yang sangat penting dan strategis dalam upaya membentuk watak bangsa dan mengembangkan potensi siswa dalam kerangka pembangunan pendidikan di Indonesia. Tampaknya kehadiran guru hingga saat ini bahkan sampai akhir hayat nanti tidak akan pernah dapat digantikan oleh yang lain, terlebih pada masyarakat Indonesia yang multikultural dan multibudaya, kehadiran teknologi tidak dapat menggantikan tugastugas guru yang cukup kompleks dan unik.

Profesionalisme guru adalah suatu tingkat penampilan seseorang dalam melaksanakan pekerjaan sebagai guru yang didukung dengan keterampilan dan kode etik. Menurut Moh Surya, eksistensi seorang guru adalah sebagai pendidik profesional disekolah, dalam hal ini guru sebagai uswatun hasanah, jabatan administratif, dan petugas kemasyarakatan. ${ }^{17}$

\footnotetext{
${ }^{17}$ Samana, Profesionalisme Keguruan, (Yogyakarta: Kanisius, 2006), hlm.13.
} 
Profesional adalah (1) bersangkutan dengan profesi, (2) memerlukan kepandaian khusus untuk menjalankannya dan (3) mengharuskan adanya pembayaran untuk melakukannya. ${ }^{18}$ Menurut Oemar Hamalik, guru profesional merupakan orang yang telah menempuh program pendidikan guru dan memiliki tingkat master serta telah mendapat ijazah negara dan telah berpengalaman dalam mengajar pada kelas-kelas besar. $^{19}$

Sikap profesional guru seperti yang di sampaikan oleh Mulyasa adalah sikap dan perilaku guru yang berhubungan dengan profesinya yaitu bagaimana perilaku guru dalam memahami, menghayati, mengamalkan kompetensi dan sikap profesionalnya. Pola dan perilaku guru tersebut berkaitan dengan figure dan teladan, sikap terhadap organisasi profesi, peraturan perundang-undangan, teman sejawat, peserta didik, lingkungan kerja, pimpinan, dan pekerjaannya. ${ }^{20}$

H.A.R. Tilaar menjelaskan seorang yang professional menjalankan pekerjaannya sesuai dengan tuntutan profesi atau dengan kata lain memiliki kemampuan dan sikap sesuai dengan tuntutan profesinya. ${ }^{21}$ Seorang profesional menjalankan kegiatannya berdasarkan profesionalisme, bukan secara amatiran. Profesionalisme bertentangan dengan amatirisme. Seorang Profesionalisme akan terus menerus meningkatkan mutu karyanya secara sadar dan pelatihan. Sutan Zanti Arbi menjelaskan profesionalisme dan profesi telah menjadi kosa kata umum. Kata profesionalisme guru merupakan kondisi, arah, nilai, tujuan dan kualitas, suatu keahlian dan kewenangan dalam bidang pendidikan dan pengajaran yang berkaitan dengan pekerjaan seseorang yang menjadi mata pencaharian. Profesionalisme menggambarkan selalu berpikir, berpendirian, bersikap, bekerja dengan sungguh-sungguh, kerja keras, bekerja sepenuh waktu, disiplin, jujur, dan loyalitas tinggi dan penuh dedikasi untuk keberhasilan pekerjaannya. $^{22}$

Seorang guru disamping harus memiliki kedalaman ilmu pengetahuan, guru mesti seorang yang bertakwa dan berakhlak atau berkelakuan baik. Perilaku guru juga merupakan dari profesionalisme dari guru itu sendiri karena secara langsung atau

\footnotetext{
${ }^{18}$ Nurdin, Syaifuddin. Guru Profesional\& Imp lementasi Kurikulum. (Jakarta: Quantum Teaching, 2005), hlm.13.

${ }^{19}$ Hamalik, Oemar. Pendidikan Guru. (Jakarta: Bumi Aksara, 2009), hlm.27.

${ }^{20}$ Mulyasa, E. Op.Cit., hlm.181.

${ }^{21}$ H.A.R., Tilaar. Membenahi Pendidikan Nasional. (Jakrta: Rineka Cipta, 2002), hlm.86.

${ }^{22}$ Achdiat, Maman. Pembentukan Profesioanal Keguruan, (Bandung: Remaja Rosdakarya, 2009), hlm. 6.
} 
tidak langsung berpengaruh terhadap motivasi belajar siswa, baik yang positif maupun yang negatif. Jika kepribadian yang ditampilkan guru seperti segala tutur sapa, sikap, dan perilaku guru itu baik, maka siswa akan termotivasi untuk belajar dengan baik. Guru profesional tidak hanya mentransfer ilmu, tetapi juga berbudi pekerti dan dapat menjadi contoh bagi siswa.

Dari beberapa pendapat dan uraian di atas maka dapat di simpulkan bahwa, profesionalisme guru adalah kemampuan guru untuk melakukan tugas pokoknya sebagai pendidik dan pengajar. Dan profesionalisme guru ini mempunyai kriteria tertentu yang dapat di lihat dan di ukur berdasarkan kompetensi yang harus di miliki oleh setiap guru.

Dalam menghadapi tuntutan situasi perkembangan zaman dan pembangunan nasional, sistem pendidikan nasional harus dapat dilaksanakan secara tepat guna dan hasil guna dalam berbagai aspek dimensi, jenjang dan tingkat pendidikan. Keadaan semacam itu pada gilirannya akan menuntut para pelaksana dalam bidang pendidikan diberbagai jenjang untuk mampu menjawab tuntutan tersebut melalui fungsi-fungsinya sebagai guru.

Sebelumnya telah disinggung mengenai guru professional yang intinya adalah guru yang memenuhi persyaratan kompetensi untuk melakukan tugas pendidikan dan pengajaran. Oleh karena itu membicarakan aspek profesionalisme guru berarti mengkaji kompetensi yang harus dimiliki seorang guru. Kompetensi dapat diartikan dengan kemampuan, kecakapan, dan wewenang.

Beberapa pengertian kompetensi seperti yang di sampaikan oleh Kompri menyebutkan bahwa:

1. Kompetensi adalah suatu kemampuan untuk melaksanakan atau melakukan suatu pekerjaan atau tugas yang dilandasi atas ketrampilan dan pengetahuan serta di dukung oleh sikap kerja yang di tuntut oleh pekerjaan tersebut.

2. Kompetensi merupakan karakteristik individu yang mendasari kinerja atau perilaku di tempat kerja.

3. Kompetensi merupakan landasan dasar karakteristik orang dan mengidikasikan cara berperilaku atau berpikir menyamakan situasi dan mendukung untuk periode waktu yang lama.

4. Kompetensi sebagai kemampuan seseorang untuk menghasilkan pada tingkat memuaskan di tempat kerja. ${ }^{23}$

\footnotetext{
${ }^{23}$ Kompri. Standarisasi Kompetensi Kepala Sekolah. (Jakarta: Kencana, 2017), hlm.1.
} 
Menurut Hamzah B Uno, kompetensi profesional guru adalah seperangkat kemampuan yang harus dimiliki oleh guru agar ia dapat melaksanakan tugas mengajar. Adapun kompetensi profesional mengajar yang harus dimiliki oleh seorang guru yaitu meliputi kemampuan dalam merencanakan, melaksanakan, dan mengevaluasi sistem pembelajaran, serta kemampuan dalam mengembangkan sistem pembelajaran. ${ }^{24}$

Mengacu pada uraian diatas, maka kompetensi profesional guru dapat diartikan sebagai kemampuan seorang guru dalam melaksanakan tugas profesi keguruan dengan penuh tanggung jawab dan dedikasi tinggi dengan sarana penunjang berupa bekal pengetahuan yang dimilikinya. Kompetensi merupakan perilaku untuk mencapai tujuan yang dipersyaratkan sesuai dengan kondisi yang dipersyaratkan pula. Kompetensi sangat diperlukan untu mengembang kualitas dan aktivitas tenaga kependidikan.

Peran guru sebagai tenaga pendidik merupakan peran- peran yang berkaitan dengan tugas-tugas memberi bantuan dan dorongan tugas pengawas dan pembina serta tugas-tugas yang berkaitan dengan mendisiplinkan anak, agar anak itu menjadi patuh terhadap aturan-aturan sekolah dan norma hidup dalam keluarga dan masyarakat. $^{25}$

Pada prinsipnya, profesionalisme guru dapat di artikan sebagai guru yang dapat menjalankan tugasnya secara professional. Untuk menentukan apakah seorang guru di katakan profesional atau tidak,dapat dilihat dari dua perspektif. Pertama, dilihat dari tingkat pendidikan, minimal dari latar belakang pendidikan untuk menjadi guru. Kedua, penguasaan guru terhadap materi bahan mengelola proses pembelajaran, pengelolaan siswa, melakukan tugas- tugas ajar, bimbingan, dan lain lain.

Sanjaya mengatakan bahwa sebagai suatu profesi terdapat sejumlah kompetensi yang harus dimiliki oleh seorang guru, yaitu kompetensi kepribadian, kompetensi pedagogik, kompetensi profesional dan kompetensi sosial kemasyarakatan. ${ }^{26}$

\footnotetext{
${ }^{24}$ Hamzah, B. Uno. Profesi Kependidikan; Problema, Solusi dan ReformasiPendidikan di Indonesia. (Bumi Aksara: Jakarta, 2007), hlm.18.

${ }^{25}$ Subini, Nini. Awas jangan Jadi Guru Karbitan. (Yogyakarta: Javalitera, 2012), hlm.16.

${ }^{26}$ Sanjaya, Wina. Pembelajaran dalam Implementasi Kurikulum Berbasis Kompetensi, (Jakarta: Kencana Prenada Media Group, 2005), hlm.146.
} 


\section{METODE PENELITIAN}

Jenis penelitian yang digunakan adalah deskriptif kualitatif. Secara teoritis, penelitian deskriptif adalah penelitian yang terbatas pada usaha mengungkapkan suatu masalah dan keadaan sebagaimana adanya sehingga hanya merupakan penyingkapan fakta dengan menganalisis data. ${ }^{27}$ Waktu penelitian adalah antara bulan Februari sampai dengan Mei 2019. Tempat penelitian adalah di SMP Negeri 40 Purworejo, Jawa Tengah.

Dalam penelitian ini, data dan informasi didapatkan dari narasumber/informan, yaitu Kepala Sekolah, Komite, Waka, Guru, TU SMP Negeri 40 Purworejo. Teknik pengumpulan data merupakan cara yang digunakan peneliti untuk memperoleh data penelitian yang dibutuhkan. Proses pengumpulan data dalam penelitian ini dilakukan dengan teknik observasi, wawancara, dan dokumentasi.

Keabsahan data dalam penelitian ini yaitu mengecek balik derajat kepercayaan suatu informasi yang diperoleh melalui waktu dan alat yang berbeda dengan jalan membandingkan data hasil pengamatan dengan hasil wawancara atau hasil dokumen lain. Dalam menguji keabsahan data peneliti menggunakan tehnik Triangulasi, yakni teknik pemeriksaan keabsahan data yang memanfaatkan sesuatu yang lain di luar data untuk keperluan pengecekan atau sebagai pembanding terhadap data itu. Itu artinya melakukan validasi, dengan cara mengecek dokumen program dan bukti tertulis lainnya. ${ }^{28}$ Dalam penelitian ini menggunakan Triangulasi metode yaitu menggunakan dua strategi yaitu: (1) Pengecekan terhadap derajat kepercayaan penemuan hasil penelitian dengan beberapa teknik pengumpulan data; (2) Pengecekan derajat kepercayaan beberapa sumber data dengan metode yang sama.

Langkah-langkah yang dilakukan penulis lakukan untuk menganalisis data yang sudah diperoleh dari hasil observasi, wawancara, dan dokumentasi yaitu dengan menggunakan model analisis data Miles dan Huberman sebagaimana yang dikutip oleh Sugiyono, yaitu reduksi data (data reduction), penyajian data (data display), dan penarikan kesimpulan (conclusion drawing/verification). ${ }^{29}$

\section{PEMBAHASAN HASIL PENELITIAN}

Hasil penelitian ini mencakup: (1) kemampuan manajerial Kepala Sekolah kaitannya dengan chief officer dalam meningkatkan profesionalisme guru di SMP

\footnotetext{
${ }^{27}$ Noeng Muhajir, Metode Penelitian Kualitatif, (Yogyakarta: Rake Saraisin, 1996), hal. 49

${ }^{28}$ Michael Quinn Patton. Metode Evaluasi Kualitatif. (Yogyakarta: Pustaka Pelajar, 2006), hal. 280

${ }^{29}$ Sugiyono, Metode Penelitian Pendidikan, (Bandung: Alfabeta. 2009), hal. 254
} 
Negeri 40 Purworejo, (2) kemampuan Sense of business Kepala Sekolah dalam meningkatkan profesionalisme guru di SMP Negeri 40 Purworejo, dan (3) kemampuan Sense of education kepala sekolah dalam meningkatkan profesionalisme guru di SMP Negeri 40 Purworejo.

\section{Kemampuan Manajerial Kepala Sekolah Kaitannya dengan Chief Officer dalam Meningkatkan Profesionalisme Guru di SMP Negeri Purworejo}

Pada dasarnya manajemen adalah suatu proses merencanakan, melembagakan, melaksanakan, memimpin dan mengendalikan usaha para anggota lembaga serta mendayagunakan seluruh sumber-sumber daya lembaga dalam rangka mencapai tujuan yang telah ditetapkan. Sedangkan kepala sekolah sebagai manajer adalah seorang perencana, organisator, pemimpin, dan pengendali semua aktivitas sekolah. Dan keberadaan manajer pada suatu organisasi (sekolah) sangat diperlukan, sebab organisasi sebagai alat mencapai tujuan organisasi.

Dalam hal kemampuan manajerial kepala sekolah kaitannya dengan chief officer dalam meningkatkan profesionalisme guru di SMP Negeri Purworejo, maka kepala sekolah harus mampu melaksanakan tiga hal sesuai perannya; membangun dan berkomitmen pada visi, misi sekolah; menciptakan suasana yang harmonis di lingkungan sekolah; memberikan kesempatan kepada tenaga kependidikan untuk meningkatkan profesinya.

Selengkapnya, berikut ini akan di jelaskan pembahasan mengenai kemampuan manajerial kepala sekolah kaitannya dengan chief officer dalam meningkatkan profesionalisme guru di SMP N 40 Purworejo:

a. Kemampuan Kepala Sekolah dalam Membangun dan Berkomitmen pada Visi dan Misi Sekolah

Kemampuan kepala sekolah kaitannya dengan chief officer dalam peningkatan profesionalisme guru yang pertama adalah dengan membangun dan berkomitmen pada visi misi sekolah. Di dalam merumuskan visi, misi sekolah adalah berdasarkan masukan dari berbagai pihak yang berkepentingan dan di putuskan oleh rapat dewan pendidik yang di pimpin oleh kepala sekolah dengan mempertimbangkan masukan dari komite. 
Kepala sekolah SMP Negeri 40 Purworejo dalam membangun dan merumuskan visi misi sekolah sudah cukup baik karena melibatkan semua pihak yang berkepentingan., sehingga akan menumbuhkan rasa kepemilikan terhadap lembaga/ sekolah, serta mensosialisikan kepada seluruh warga sekolah dan masyarakat.

Hasil observasi dan dokumentasi yang peneliti lakukan, bahwa selama kepemimimpinan kepala sekolah, terdapat beberapa program yang direncanakan telah di laksanakan, di antaranya adalah adanya program rapat dengan para guru, supervisi dan kunjungan kelas yang dilakukan kepala sekolah. Visi dan misi sekolah sudah dilaksanakan dengan baik walaupun masih belum semuanya, karena memerlukan kerja sama yang baik untuk melaksanakan visi dan misi ini sehingga dapat tercapai apa yang menjadi tujuan sekolah.

b. Membangun Kerja Sama Tim (Team Work) Antar Guru dan Staf, dan Menjaga Keharmonisan di Lingkungan Sekolah

Pengaturan suasana kerja yang tenang dan menyenangkan serta kerja sama yang baik di antara guru dan staf akan membangkitkan semangat guru dalam bekerja, selain itu pengaturan lingkungan fisik yang kondusif, adanya tata tertib dan budaya sekolah yang di laksanakan oleh warga sekolah, akan dapat menumbuhkan produktifitas kinerja guru dalam melaksanakan tugasnya.

Dari hasil wawancara dan observasi dan dokumentasi di lapangan dapat di ketahui bahwa kepala sekolah dalam mengatur dan mengelola bawahannya adalah dengan menciptakan suasana yang harmonis di sekolah, hal ini sangat perlu untuk di laksanakan agar di dalam pengeloaan tenaga pendidikan lebih mudah dan lebih maksimal.

Kepala sekolah SMP Negeri 40 Purworejo telah berupaya untuk menciptakan team work, suasana yang harmonis di sekolah dengan; memberikan tugas kepada guru sesuai dengan kemampuan dan latar belakang pendidikannya, dan guru dapat melaksanakan tugas sesuai dengan tupoksinya masing- masing.

Di tahun pelajaran kepala sekolah telah membuatkan SK pembagian tugas guru; menganggap guru bukan sebagai bawahan tetapi sebagai rekan kerja. Hal ini dapat di buktikan dengan kerja sama yang baik, terjalinnya suasana yang 
akrab dan harmonis di antara para guru, bahkan warga sekolah dapat mentaati tata tertib sekolh yang sudah di sepakati, sehingga di SMP Negeri 40 Purworejo, proses pembelajaran sekolah dapat berjalan dengan baik dan kondusif, hal ini tentu saja dapat memberikan semangat bagi guru untuk dapat melaksanakan pembelajaran dengan baik pula.

c. Memberi Kesempatan Kepada Tenaga Kependidikan untuk Meningkatkan Profesinya

Pelaksanaan pembelajaran merupakan langkah awal untuk merealisasikan konsep pembelajaran dalam bentuk perbuatan. Dan dalam usaha meningkatkan profesinya, guru dapat mengikuti forum ilmiah seperti seminar, pelatihan/ workshop dan MGMP bagi guru sangatlah penting untuk menambah wawasan serta ilmu yang akan dapat menambah dan meningkatkan kemampuan kinerja guru terutama dalam kegiatan pembelajaran.

Kepala sekolah SMP Negeri 40 Purworejo telah memberikan kesempatan kepada guru untuk mengikuti kegiatan- kegiatan yang dapat meningkatkan kompetensi dan kinerja guru, seperti seminar, workshop ataupun MGMP. Bahkan salah satu program kepala sekolah adalah memfasilitasi Bapak ibu guru untuk melaksanakan workshop secara mandiri seperti workshop tentang pembuatan PTK maupun yang akan melakukan seminar karya ilmiah, maka sekolah akan bekerja sama dengan sekolah lain yang ada di sekitar sub rayon 07 dan Dinas terkait agar acara tersebut dapat berjalan dengan lancar.

Dengan mengikuti seminar, workshop dan MGMP di maksudkan agar ilmunya dapat di implementasikan di dalam meningkatkan kompetensi sebagai seorang guru. Dan ini dapat dilihat dari semangat guru dalam melaksanakan pembelajaran dan kesadaran guru dalam membuat Perangkat Pembelajaran

\section{Kemampuan Sense of Business Kepala Sekolah dalam Kaitannya Meningkatkan Profesionalisme Guru di SMP Negeri 40 Purworejo}

Pendidikan merupakan tanggung jawab orang tua siswa, masyarakat, dan pemerintah. Dan suatu sistem pendidikan akan dapat dilaksanakan dan berhasil mencapai sasaran atau untuk mewujudkan visi dan misi sekolah apabila didukung oleh pendanaan yang memadai. Oleh karena itu, keuangan dan pembiayaan merupakan salah satu sumber daya yang secara langsung menunjang efektivitas dan 
efisiensi pengelolaan pendidikan. Kepala sekolah dalam pengelolaan keuangan sekolah harus dilakukan melalui perencanaan, pengorganisasian, pelaksanaan,dan evaluasi. Kemampuan kepala sekolah sense of business yang di maksud adalah:

a. Merencanakan Anggaran Dana Pendidikan

Di dalam proses perencanaan anggaran sekolah kepala sekolah harus terlebih dahulu mengetahui dari mana sumber dana yang diperoleh, sehingga dapat merencanakan pengeluaran untuk kegiatan belajar mengajar, pengadaan dan pemeliharaan sarana dan prasarana, pengembangan sumber belajar dan alat pelajaran serta honorarium dan kesejahteraan. Dan dalam penyusunan Rencana Kegiatan dan Anggaran Sekolah (RKAS) harus digerakkan oleh visi misi yang jelas. Karena anggaran yang digerakkan oleh visi misiakan memberikan dampak positif terhadap pencapaian tujuan pendidikan.

Sumber dana atau biaya pendidikan adalah keseluruhan biaya yang berasal dari masyarakat, orang tua, dan pemerintah. Sumber dana pendidikan dari pemerintah pusat berupa Bantuan Operasional Sekolah (BOS) yang sudah ditentukan jumlahnya berdasar pada karakteristik siswa dan jenjang pendidikanya. Dana pendidikaan SMP Negeri 40 Purworejo bersumber dari Pemerintah, Pemerintah Daerah dan masyarakat.

Dari hasil observasi, wawancara dan dokumentasi menunjukkan bahwa di SMP Negeri 40 Purworejo sumber dana pendidikan untuk menunjang kelangsungan operasional dan kegiatan pendidikan di sekolah masih bergantung pada dana yang berasal dari pemerintah yaitu dana BOS, dan dana dari wali siswa yaitu dana dari komite sekolah.

Sedangkan besarnya dana dari Komite sekolah yang menentukan adalah anggota komite sekolah yang di musyawarahkan di dalam rapat komite sekolah di pimpin oleh ketua komite sekolah. Dari hasil wawancara peneliti menunjukkan bahwa untuk perencanaan ini terutama dalam pencarian sumber dana operasional sekolah masih minim sekali dan sangat perlu untuk dikembangkan.

b. Pelaksanaan Dana Pendidikan

Sekolah dalam pelaksanaan dana pendidikan sekolah haruslah menggunakan RKAS sebagai acuan dalam pelaksanaan kegiatan, namun sekolah masih bisa merubah RKAS itu jika dalam kondisi tertentu yang memang memerlukan 
perubahan.

Di SMP Negeri 40 Purworejo di dalam pelaksanaan dana pendidikan berusaha agar sesuai dengan RKAS yang telah di susun. Bila ada perubahan program pada ranah delapan stándar, maka akan di ajukan revisi, sehingga sekolah tetap dapat melaksanakan kegiatan-kegiatan yang harus di laksanakan".

c. Mengendalikan Serta Mempertanggung Jawabkan Dana Pendidikan

Di dalam pengelolaan dana pendidikan prinsip akuntabilitas dan transparansi diperlukan adanya pemantauan dan supervisi sebagai alat pengendali, sehingga dapat dipastikan kegiatan yang dilaksanakan sekolah telah sesuai dengan tujuan yang telah ditetapkan. Di SMP Negeri 40 Purworejo kepala Sekolah selaku pengendali kegiatan, memberikan kewenangan penuh kepada bendahara dengan tetap berpegang pada prosedur yang ada. Hal ini menunjukkan bahwa kepala sekolah di dalam pengelolaan dana pendidikan sudah berjalan dengan baik dan lancar.

\section{Kemampuan Sense of Education Kepala Sekolah dalam Kaitannya} Meningkatkan Profesionalisme Guru di SMP Negeri 40 Purworejo

Sebagai kepala sekolah harus berusaha menanamkan, memajukan dan meningkatkan sedikitnya empat macam nilai, yakni pembinaan mental, moral, fisik dan artsitik. Hal ini dapat di jelaskan sebagai berikut:

a. Pembinaan Mental

Membina para tenaga kependidikan tentang hal-hal yang berkaitan dengan sikap, batin dan wataknya maka kepala sekolah harus mampu menciptakan iklim yang kondusif agar setiap tenaga kependidikan dapat melaksanakan tugas dengan baik, proposional dan profesional. Oleh karena itu kepala sekolah berusaha melengkapi sarana, prasarana dan sumber belajar akan memberikan kemudahan kepada guru dalam melaksanakan tugas utamanya mengajar.

Dari hasil obsevasi, wawancara dan dokumentasi di SMP Negeri 40 Purworejo ketersediaan sarana, prasarana dan sumber belajar sangat membantu dan mutlak dibutuhkan untuk menunjang proses dan kegiatan belajar mengajar $(\mathrm{KBM})$, dalam hal ini adalah penyediaan sumber belajar seperti sarana internet agar para guru dapat mengakses informasi-informasi baru yang mendukung terhadap pengembangan keilmuan dan profesionalnya, pengadaan bahan bacaan 
baru seperti buku, majalah kependidikan, jurnal kependidikan, sebagai tambahan sumber belajar juga menunjang terhadap peningkatan kinerja guru

Ketersediaan sarana dan prasana serta fasilitas yang menunjang kegiatan pembelajaran menyebabkan pelaksanaan pembelajaran berjalan dengan kondusif, hal ini menunjukkan kepala sekolah mampu melaksankan pembinaan mental bagi para tenaga pendidikan.

b. Pembinaan Moral

Pembinaan tenaga kependidikan ini berkaitan dengan ajaran baik buruk suatu perbuatan, sikap, hak dan kewajiban sesuai dengan tugas masing-masing tenaga kependidikan. Kepala sekolah profesional harus berusaha memberikan nasehat kepada seluruh warga sekolah, misalnya, pada setiap upacara bendera atau pertemuan- pertemuan rutin lainnya seperti dalam ralam rapat dewan guru atau yang lainnya.

Tugas dan tanggung jawab utama guru di suatu satuan pendidikan, mencakup mendidik, mengajar, membimbing, mengarahkan, melatih, menilai dan mengevaluasi peserta didik. Untuk menunjang pelaksanaan tugas dan tanggung jawab pokok tersebut, guru juga dituntut untuk melaksanakan tugas dan tanggung jawab lainnya, yaitu menyangkut administrasi kelas, pengembangan kurikulum, mengembangkan profesi atau bertindak sebagai ilmuwan, membina hubungan dengan masyarakat atau bertindak sebagai penghubung dan pembaharu dalam masyarakat, memiliki kepribadian atau akhlaq yang mantap, serta berkepribadian (berjiwa) Pancasilais dan nasionalis.

Berdasarkan hasil observasi, wawancara meunjukkan bahwa kepala sekolah SMP Negeri 40 Purworejo melaksanakan pembinaan moral kepada semua warga sekolah termasuk kepada guru, baik mengenai tugas dan tanggung jawab sebagai guru, kedisiplinan, patriotism dan nasionalisme. Kepala sekolah tidak hanya memberi dorongan atau motivasi saja melainkan juga member contoh dan keteladanan kepada seluruh warga sekolah terutama dalam kedisiplinan.

c. Pembinaan Fisik

Pembinaan ini adalah pembinaan tenaga kependidikan tentang hal-hal yang berkaitan dengan kondisi jasmani atau badan, kesehatan dan penampilan mereka secara lahiriah. Kepala sekolah secara profesional harus mampu memberikan 
dorongan agar para tenaga kependidikan untuk terlibat secara aktif dan kreatif dalam berbagai kegiatan olah raga, baik yang diprogramkan di sekolah maupun yang diselenggarakan oleh masyarakat di sekitar sekolah.

Berkaitan dengan pembinaan fisik ini, kepala sekolah SMP Negeri 40 Purworejo selalu aktif untuk selalu mengingatkan kepada seluruh warga sekolah, terutama bapak/ ibu guru untuk selalu menjaga kesehatan, dengan melaksanakan olah raga secara rutin dan menjaga penampilan agar terlihat bugar dan penuh semangat dalam beraktifitas. Hasil observasi menunjukkan bahwa program yang ada di SMP Negeri 40 Purworejo, salah satunya adalah melaksanakan Jum'at sehat atau Jum'at bersih secara bersama, yang di adakan di sekolah dalam seminggu sekali.Hal ini menunjukkan bahwa kepala sekolah sudah melaksanakan pembinaan fisik kepada seluruh warga sekolah terutama guru.

d. Pembinaan Artistik

Pembinaan tenaga kependidikan dalam hal ini adalah pembinaan yang berkaitan dengan kepekaan manusia terhadap seni dan keindahan. Di dalam rutinitas pekerjaan sehari-hari, guru juga memerlukan waktu untuk rehat dan istirahat. Banyak sebenarnya pilihan untuk melakukan rekreasi, apalagi jika dilakukan bersama-sama. Semakin menambah rasa keakraban terhadap sesama. Rekreasi ataupun karya wisata bisa memilih di tempat-tempat peninggalan bersejarah jika akan menambah pengetahuan dan juga wawasan, bisa ke hutan lindung atau tempat-tempat penangkaran binatang jika hal itu dapat menambah pengetahuan dan juga rasa sayang kepada makhluk hidup lainnya.

Kepala sekolah SMPN 40 Purworejo di bantu oleh waka yang lain telah memprogramkan di dalam setiap semester atau setahun sekali yaitu karyawisata atau rekreasi bersama Bapak/ibu guru SMPN 40 Purworejo dengan tujuan untuk membina jiwa akan seni juga keindahan, sekaligus menghilangkan kejenuhan karena kesibukan dengan tugas kesehariannya. Dengan wisata ini di harapkan dapat menghilangkan kepenatan sekaligus melatih kepekaan guru terhadap seni dan keindahan alam sehingga menumbuhkan jiwa seni yang kreatif, cinta akan keindahan alam dan lingkungan sekitar. 


\section{KESIMPULAN DAN SARAN}

\section{Kesimpulan}

Berdasarkan hasil penelitian yang telah dilakukan, maka dapat diambil kesimpulan sebagai berikut:

1. Kemampuan manajerial Kepala Sekolah kaitannya dengan chief officer dalam meningkatkan profesionalisme guru di SMP Negeri 40 Purworejo di antaranya adalah mengedepankan membangun dan berkomitmen terhadap visi, misi sekolah; menciptakan hubungan yang harmonis di lingkungan sekolah; dan memberi kesempatan guru untuk menigkatkan profesinya. Hal yang membuktikan adanya kemampuan chief officer kepala sekolah SMP Negeri 40 Purworejo salah satunya adalah sudah adanya visi misi sekolah yang merupakan hasil keputusan bersama, sehingga menumbuhkan rasa peduli dan memiliki kepada lembaga/ sekolah. Visi dan misi inipun sudah tersosialisasikan dengan baik kepada seluruh warga sekolah dan pihak terkait. Sudah terlaksananya program dan tujuan sekolah meskipun belum seluruhnya tercapai, menunjukkan komitmen kepala sekolah dalam upaya meningkatkan profionalisme guru, dan untuk mencapai visi dan misi serta tujuan sekolah diperlukan kerja sama yang baik antara kepala sekolah dan semua elemen sekolah di antaranya adalah guru dan masyarakat. Dengan di berikan SK Pembagian Tugas guru di awal tahun Pelajaran, maka guru di SMP Negeri 40 Purworejo dapat menjalankan tugas dan tanggungjawabnya sesuai dengan tupoksinya masing-masing yang di sesuaikan dengan latar belakang pendidikannya. Kepal sekolah SMP Negeri 40 Purworejo berusaha untuk membangun team work dalam melaksanakan tugas dengan membentuk kepanitiaan dalam setiap kegiatan sekolah. Tenaga kependidikan di berikan kesempatan untuk meningkatkan profesinya melalui seminar, MGMP,dan workshop, dll.

2. Kemampuan Sense of business Kepala Sekolah dalam meningkatkan profesionalisme guru di SMP Negeri 40 Purworejo, hal ini dibuktikan dengan kemampuan kepala sekolah di dalam mengelola dana pendidikan termasuk pencarian sumber dana pendidikan yang berasal dari dana BOS dan dari komite sekolah untuk mencukupi biaya operasional di sekolah. Di dalam perencanaan dan anggaran sekolah kepala sekolah harus terlebih dahulu mengetahui dari mana sumber dana yang diperoleh, sehingga dapat merencanakan pengeluaran untuk kegiatan belajar mengajar, seperti 
pengadaan dan pemeliharaan sarana dan prasarana, pengembangan sumber belajar dan alat pelajaran serta honorarium dan kesejahteraan. Namun kepala sekolah juga harus dapat mengendalikan dan mempertanggung jawabkan dana pendidikan yang di peroleh untuk kepentingan operasinal pendidikan di sekolah dengan baik.

3. Kemampuan Sense of education kepala sekolah dalam meningkatkan profesionalisme guru di SMP Negeri 40 Purworejo, merupakan salah satu usaha yang di lakukan oleh kepala sekolah dalam melakukan pembinaan kepada seluruh warga sekolah teutama tenaga pendidik yang meliputi pembinaan mental, pembinaan moral, pembinaan fisik, dan pembinaan artistik. Hal ini dapat di buktikan dengan sudah terselenggaranya program kegiatan pembinaan tersebut yang pada akhirnya menunjukkan bahwa guru di SMP Negeri 40 Purworejo mempunyai semangat tinggi di dalam menjalankan tugas terutama dalam pembelajaran, mempunyai kedisiplinan yang cukup baik.

\section{Saran-saran}

Berdasarkan hasil dari penelitian yang dilakukan, maka penulis memberi saran sebagai berikut:

1. Terkait kemampuan manajerial Kepala Sekolah kaitannya dengan chief officer dalam meningkatkan profesionalisme guru di SMP Negeri 40 Purworejo, seorang pemimpin/ kepala sekolah dalam meningkatkan profesionalisme guru, hendaknya kepala sekolah dapat melakukan kepemimpinan dengan baik, demokratis, salah satunya dengan bekerja sama dengan warga sekolah untuk mencapai visi misi sekolah yang telah di rumuskan bersama. Dengan kepemimpinan yang baik akan terjalin hubungan yang hamonis di antara warga sekolah, silaturrami yang tetap terjaga terutama hubungan antara kepala sekolah dengan para guru. Dengan memberi kesempatan guru untuk meningkatkan profesinya melalui seminar, workshop, MGMP akan dapat memberikan wawasan, ilmu yang bermanfaat bagi guru sehingga guru tidak lagi terhambat dalam melaksanakan tugasnya karena tidak lengkapnya administrasi yang di buat oleh guru, dan guru dapat bekerja sesuai tupoksinya masing- masing.

2. Kemampuan Sense of business Kepala Sekolah dalam meningkatkan profesionalisme, maka kepala sekolah harus dapat mengelola dana terutama dalam mencari sumber dana dalam memenuhi kebutuhan operasional sekolah. Kepala 
sekolah harus mampu merencanakan anggaran sekolah dan mengetahui sumber dana yang di peroleh sehingga dapat pula merencanakan pengeluaran yang tertuang dalam RKAS. Selain itu, juga kepala sekolah harus dapat mengendalikan dan mempertanggung jawabkan dana pendidikan yang di peroleh baik dana dari BOS maupun dari komite sekolah.

3. Kemampuan Sense of education kepala sekolah dalam meningkatkan profesionalisme guru di SMP Negeri 40 Purworejo, maka dalam menerapkan kepemimpinan kepada para guru yang dipimpinnya, kepala sekolah hendaknya berupaya untuk dapat melakukan pembinaan- pembinaan, pengarahan dan nasehatnasehat yang baik kepada guru minimal empat macam pembinaan yaitu pembinaan mental, pembinaan moral, pembinaan fisik dan pembinaan artistik. Semua itu di laksanakan untuk memberi motivasi kepada warga sekolah terutama kepada guru untuk menjadi pribadi yang lebih baik dan semakin bersemangat dalam melaksanakan tugas- tugasnya, berpenampilan menarik, sehat juga disiplin yang tinggi yang dapat menjadi teladan bagi siswanya.

\section{DAFTAR PUSTAKA}

Achdiat, Maman. Pembentukan Profesioanal Keguruan, Bandung: Remaja Rosdakarya, 2009.

Arifin, Anwar. Strategi Komunikasi, Sebuah Pengantar Ringkas. Bandung: Armico, 1994.

Arikunto, Suharsimi. Manajemen Pengajaran Secara Manusiawi, Jakarta: Rineka Cipta, 2010.

Busher,H. Understanding educational leadership: Peopele, power, and culture. New York: Open Uunivercity Press, 2003.

Danim, Sudarwan. Visi Baru Manajemen, Jakarta: Bumi Aksara, 2005.

Eliyanto. Manajemen Sumber Daya Manusia (MSDM) Pendidikan. Yogyakarta: UIN Sunan Kalijaga, 2018.

UU RI No. 14 Tahun 2005 tentang Guru dan Dosen.

UU RI No 20 Tahun 2003 tentang SISDIKNAS.

Hamalik, Oemar. Pendidikan Guru. Jakarta: Bumi Aksara, 2009.

Hamzah, B. Uno. Profesi Kependidikan; Problema, Solusi dan ReformasiPendidikan di Indonesia. Bumi Aksara: Jakarta, 2007.

H.A.R.,Tilaar. Membenahi Pendidikan Nasional. Jakrta: Rineka Cipta, 2002. 
Huber, S.G. 2004. Scool leadership and leadership development. Adjusting leadership teories and development program to values and the core of scool. (Jurnal of Educatiaon Administrasion, Vol.42, No.6, Th.2004.

Khan, M.M.,et al. Transformasional, transactional, and laissez-fier.e style of teaching faculty as pradictors of satisfaction, and extra effort among the studens: Evidence from higher education institution. Interdisciplinery. Journal of Human And Social Sciences, Vo.3, No.6, Th.2011.

Kompri. Standarisasi Kompetensi Kepala Sekolah. Jakarta: Kencana, 2017.

Michael Quinn Patton. Metode Evaluasi Kualitatif. Yogyakarta: Pustaka Pelajar, 2006.

Mulyasa, E. Uji Kompetensi dan Penilaian Kinerja Guru. Bandung: Remaja Rosda Karya, 2017.

Noeng Muhajir, Metode Penelitian Kualitatif, Yogyakarta: Rake Sarasin, 1996.

Nurdin, Syaifuddin. Guru Profesional\& Imp lementasi Kurikulum. Jakarta: Quantum Teaching, 2005.

Reinhartz \& Beach. Educational leadership: Changing scool, changing rooles. Boston: pearson Education, 2004.

Samana, Profesionalisme Keguruan, Yogyakarta: Kanisius, 2006.

Sanjaya, Wina. Pembelajaran dalam Implementasi Kurikulum Berbasis Kompetensi, Jakarta: Kencana Prenada Media Group, 2005.

Soetjipto, dkk, Profesi Keguruan, Jakarta: Rineka Cipta, 2009.

Subini, Nini. Awas jangan Jadi Guru Karbitan. Yogyakarta: Javalitera, 2012.

Sugiyono, Metode Penelitian Pendidikan, Bandung: Alfabeta. 2009.

Syafaruddin. Manajemen Mutu Terpadu dalam Pendidikan. Jakarta: Grasindo Widia Sarana Indonesia, 2002.

Wahyosumidjo. Kepemimpinan Kepala Sekolah Tinjauan Teoritik Dan Permasalahannya. Jakarta: Raja Grafindo Persada, 2010. 